\title{
RICKETTSIAL SPOTTED FEVER IN CAPOEIRÃO VILLAGE, ITABIRA, MINAS GERAIS, BRAZIL
}

\author{
Manoella Campostrini Barreto VIANNA(1), Maurício Claudio HORTA(1), Luis Antônio SANGIONI(1), Adriana CORTEZ(1), Rodrigo Martins SOARES(1), \\ Cláudio Lisias MAFRA(2), Márcio Antônio Moreira GALVÃO(3), Marcelo Bahia LABRUNA(1) \& Solange Maria GENNARI(1)
}

\begin{abstract}
SUMMARY
The present study investigated the infection by spotted fever rickettsia in an endemic area for Brazilian spotted fever (BSF; caused by Rickettsia rickettsii) in Minas Gerais State, Brazil. Human, canine and equine sera samples, and Amblyomma cajennense adult ticks collected in a rural area of Itabira City, Minas Gerais State were tested for rickettsial infection. Through Immunofluorescence Assay (IFA) we demonstrated the presence of antibodies anti-R. rickettsii in $8.2 \%, 81.3 \%$ and $100 \%$ of the human, canine and equine sera, respectively. None of the 356 tick specimens analyzed were positive for Rickettsia by the hemolymph test or Polymerase Chain Reaction technique (PCR) for the htrA and the gltA genes. Our serological results on horses and dogs (sentinels for BSF) appoint for the circulation of a SFG Rickettsia in the study area, however in a very low infection rate among the A. cajennense tick population.
\end{abstract}

KEYWORDS: Spotted fever; Rickettsia rickettsii; Indirect Immunofluorescence Assay; PCR; Itabira.

\section{INTRODUCTION}

Rickettsiae are strictly intracellular bacteria, transmitted to humans mainly by infected arthropods. The genus Rickettsia has been classically divided into two groups, the typhus group (TG) and the spotted fever group (SFG), which has ticks as their major reservoirs ${ }^{25}$.

Brazilian spotted fever (BSF) is a tick borne disease caused by the bacterium Rickettsia rickettsii, a SFG rickettsia. BSF was initially reported in Brazil in $1929^{27}$, and has been increasingly reported over the last 20 years. Cases are known to occur in the Southeastern states of São Paulo, Minas Gerais, Rio de Janeiro, and Espírito Santo ${ }^{7,17,19,20,21,29,32}$. Minas Gerais has been reported as the highest prevalence state ${ }^{17}$, although São Paulo has an increasing number of cases reported recently ${ }^{5}$. The main vector of BSF is the tick Amblyomma cajennense ${ }^{9,30}$, although in areas of the Atlantic rain forest Amblyomma aureolatum has also been identified as a vector ${ }^{26}$. The $A$. cajennense has a low parasitic specificity and is the main tick infesting humans in Brazil ${ }^{1,13}$. Horses (Equus caballus), tapirs (Tapirus terrestris) and capybaras (Hydrochoerus hydrochaeris) are considered its main primary hosts in Brazil ${ }^{13}$.

We performed a serological survey with humans and animals and collected ticks and epidemiological data related to Brazilian Spotted Fever in a BSF-endemic area of Minas Gerais State, Brazil.

\section{MATERIAL AND METHODS}

Study area: The study was performed in Capoeirão Village (Fig. 1), a rural area of Itabira Municipality, Minas Gerais State, southeastern Brazil $\left(19^{\circ} 43^{\prime} 30.8 \mathrm{~S}, 43^{\circ} 15^{\prime} 39.2 \mathrm{~W}\right)$. It is considered an endemic area for BSF within the state. From 1999 to April 2002, 18 cases of BSF from Capoeirão Village were reported to the Itabira Health System. Only seven of these cases were laboratory-confirmed as BSF by IFA, from which three of them resulted in death. Two other cases without serological confirmation were also fatal, although they were clinically

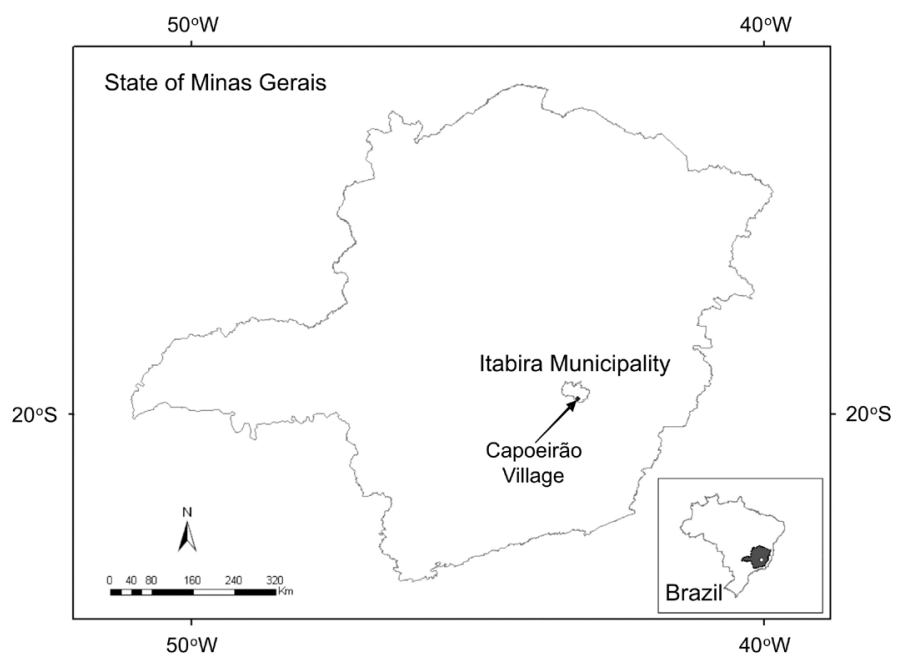

Fig. 1 - Localization of Capoeirão Village, within Itabira Municipality in the State of Minas Gerais, Brazil.

(1) Faculty of Veterinary Medicine, Preventive Veterinary Medicine Department, University of São Paulo, São Paulo, SP, Brazil.

(2) Biochemistry and Molecular Biology Department, Federal University of Viçosa, Viçosa, MG, Brazil.

(3) Clinical and Social Nutrition, Federal University of Ouro Preto, Ouro Preto, MG, Brazil.

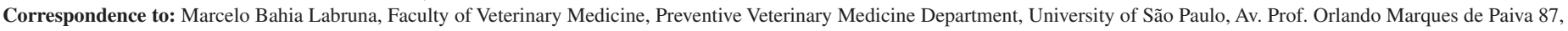
05508-000, São Paulo, SP, Brazil. E-mail: labruna@usp.br 


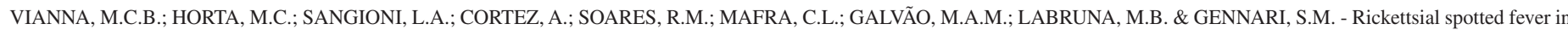
Capoeirão village, Itabira, Minas Gerais, Brazil. Rev. Inst. Med. trop. S. Paulo, 50(5): 297-301, 2008

and pathologically compatible with BSF. The remaining nine cases were not fatal and were not laboratory-confirmed. The village is surrounded by mountains and is isolated from other inhabited areas. Horses and dogs have free access to forest areas surrounding the village. Houses were built with wood or adobe and many of them were not served with treated water. Human occupations were agriculture, hunting, and lumberjack for men and household activities for women. The village population at the time of this study was estimated to be 80 persons. All of them were AfricanAmericans and most of the families were blood related.

Human and domestic animals: During February 2000, nurses from Itabira Municipal Hospital collected blood samples from 73 human residents of the village. The remaining human residents ( $\approx 7$ persons) did not agree having their blood drawn or were newborns. At that time each household was instructed to complete an epidemiology questionnaire. Blood samples were also collected from all equids present in the village (a total of 11 horses and three donkeys), and from 16 domestic dogs. Many other dogs were away from the village at collection time and could not be bled. All serum samples were centrifuged at 2,500 rpm (10 min), aliquoted, transported to the Parasitic Diseases Laboratory, Faculty of Veterinary Medicine, São Paulo University and kept frozen until used. The present study was submitted to and approved by the Research Ethics Committee of the University of São Paulo.

Immunofluorescence Assay (IFA): IFA was performed with $R$. rickettsii antigen as previously described ${ }^{35}$. Sera were diluted in Phosphate Buffered Saline solution (PBS) and screened at the 1:64 dilution. Briefly, 10 microliters of diluted sera were added to each well of the antigen slides, the slides were incubated, washed, then incubated with fluorescein isothiocyanate-labeled goat anti-human IgG, goat antihorse IgG, or goat anti-dog IgG (Kirkegaard and Perry Laboratories, Inc., Gaithersburg, MD) and washed again. The slides were mounted with Gel Mount (Biomeda, Foster City, CA) under coverslips. The slides were read using an ultraviolet microscope (BX60; Olympus, Tokyo, Japan) at 400× magnification. On each slide, a serum previously shown to be non-reactive (negative control) and a known reactive serum (positive control) were tested. Sera reacting at the screening dilution $(1: 64)$ were then tested in serial two-fold dilutions to determine the endpoint titer.

Ticks: Ticks were collected during February of two consecutive years (2000 and 2001), since the period between November and March is reported as the season with highest activity of the adult stage of $A$. cajennense ${ }^{14,23}$. Unfed adult ticks were obtained from the pastures by dragging and from the forest by $\mathrm{CO}_{2}$ traps $^{23}$. On the first year, ticks were also manually collected while attached to horses and dogs due to a low number obtained from the pastures and forest areas. All ticks were stored in appropriate containers and transported by vehicle to the laboratory in São Paulo, where they were kept for at least $24 \mathrm{~h}$ at $23{ }^{\circ} \mathrm{C}$ and $90 \%$ humidity, for reestablishment of their hydric balance.

Hemolymph test: The hemolymph test was performed as previously described $^{2}$. Briefly, each tick had one to two drops of hemolymph deposited on a glass slide, air dried and stained by the Gimenez method ${ }^{8}$. Ticks were frozen at $-80^{\circ} \mathrm{C}$ until used for DNA extraction. At this time ticks were also taxonomically identified.

DNA extraction: Ticks were individually processed for DNA extraction. Each tick was washed with $70 \%$ alcohol for 10 minutes, rinsed in sterile water and air-dried. Free-living ticks were longitudinally cut with a sterile razor, one of the halves stored frozen for further studies. Engorged ticks had the legs cut and used for DNA extraction, in order to avoid the presence of animal blood and its inhibitors ${ }^{11}$. DNA extraction was performed using the guanidine thiocyanate protocol, as described by SANGIONI et. al..$^{30}$.

Polymerase Chain Reaction (PCR): Five microliters of extracted DNA was used as a template for each reaction. Portions of the htrA and gltA genes (citrate synthase) were targeted for detection and characterization, respectively. A PCR was employed for the htrA gene as previously described $^{34}$ and followed by a nested-PCR. The nested primers were described by SCHRIEFER et al. ${ }^{31}$ Primers and PCR conditions for the $g l t A$ gene were described by REGNERY et al. ${ }^{28}$. Ten microliters of PCR product underwent electrophoresis in $2 \%$ agarose gel, which was ethidium bromide stained and observed under UV light. Negative and positive controls were included in each set of reactions. A. cajennense experimentally infected with Rickettsia parkeri ${ }^{30}$ were used as positive controls.

\section{RESULTS}

IFA: Sera with titers $\geq 64$ were considered positive. Antibodies anti- $R$. rickettsii were detected in six (8.2\%), 13 (81.3\%), 11 (100\%), and three $(100 \%)$ of the human, canine, horse, and donkey sera, respectively (Table 1).

Ticks: All collected ticks were identified as A. cajennense. From a total of 356 specimens, 140 were collected from animals and 216 were free-living ticks. None of the specimens presented a positive result on the hemolymph test. The ticks were also all negative for the PCR technique, both for the $h t r A$ and the $g l t A$ gene proteins. In all reactions the positive controls ( $R$. parkeri infected ticks DNA) demonstrated the expected bands. Besides $A$. cajennense, the only other tick species found in the village were Anocentor nitens on the horses and Boophilus microplus on cattle. These ticks were not collected for the present study.

Epidemiological data: Fourteen questionnaires were obtained out of 16 families living in the village. In 14 families, at least one person used to go inside forest areas at least once a month, but frequently men would go daily. All respondents referred to have seen ticks on their clothing and/or skin, as well as parasitizing their dogs. All but one referred to have been bitten by ticks. The human age range in the village was 3-82 years old (mean: $28.2 \pm$ [20.9]). Eleven families had dogs, but only one kept their dogs enclosed on the yard. Dogs had free access to forest areas and usually would go along with their owners for hunting. Most dogs had also free access to the home indoors. The only tick control method applied on the dogs was sporadic fumigation by the Itabira Municipality Service. There was no fence between pastures and forest areas and there was no enclosed area for the horses. Equines received sporadic fumigation for tick control, along with the dogs. Other domestic animals present in the village in order of frequency were cattle, chickens, ducks, pigs and one cat. Wild animals commonly seen around the village were rabbits (Sylvilagus brasiliensis), opossums (Didelphis sp.), and cavies (Cavia aperea), followed by foxes (Cerdocyon thous), nutria (Myocastor coypus), armadillos (Dasypus sp.), coatis (Nasua nasua), and pacas (Agouti paca). There was no report of capybaras (Hydrochoerus hydrochaeris) or tapirs (Tapirus terrestris) in the area. 
VIANNA, M.C.B.; HORTA, M.C.; SANGIONI, L.A.; CORTEZ, A.; SOARES, R.M.; MAFRA, C.L.; GALVÃO, M.A.M.; LABRUNA, M.B. \& GENNARI, S.M. - Rickettsial spotted fever in Capoeirão village, Itabira, Minas Gerais, Brazil. Rev. Inst. Med. trop. S. Paulo, 50(5): 297-301, 2008.

Table 1

Results of IFA for R. rickettsii antigen tested with human and animal sera from Capoeirão Village, Minas Gerais State, Brazil

\begin{tabular}{|c|c|c|c|c|c|c|c|c|c|}
\hline \multirow[t]{2}{*}{ Sera } & \multirow[t]{2}{*}{ Tested sera } & \multicolumn{7}{|c|}{ Number of reactive sera according to the IFA titers } & \multirow[t]{2}{*}{ Total (\%) } \\
\hline & & 64 & 128 & 256 & 512 & 1,024 & 2,048 & 4,096 & \\
\hline Humans & 73 & 4 & 0 & 1 & 1 & 0 & 0 & 0 & $6(8.20)$ \\
\hline Dogs & 16 & 10 & 3 & 0 & 0 & 0 & 0 & 0 & $13(81.3)$ \\
\hline Horses & 11 & 0 & 0 & 1 & 3 & 3 & 2 & 2 & $11(100)$ \\
\hline Donkeys & 3 & 0 & 0 & 1 & 1 & 1 & 0 & 0 & $3(100)$ \\
\hline
\end{tabular}

\section{DISCUSSION}

We found $100 \%$ of equines, $81.3 \%$ of dogs and $8.2 \%$ of humans with serologic evidence of spotted fever group rickettsial infection. This pattern of a higher frequency of serological positivity among horses, followed by dogs and humans is similar to others BSF-endemic areas where $A$. cajennense has been incriminated as the vector ${ }^{6,12,17,18,30}$. However, the prevalence rates reported in the present study are higher than those reported in others studies performed in Brazil. This difference might be related to the high endemicity of the area (as indicated by several human cases of BSF reported during the time of the present study) and to the frequent contact between humans, wild animals and domestic animals.

Horses are one of the primary hosts for A. cajennense ticks and have been previously shown to be a useful sentinel animal ${ }^{12,18,30}$; our results confirm this fact. We found $100 \%$ of the animals to be reactive, with antibody titers as high as 4,096. All donkeys were also reactive, in spite of the significant resistance that they demonstrate against $A$. cajennense ticks ${ }^{4}$. To the best of our knowledge, this is the first report of serologically positive donkeys for $R$. rickettsii antigens.

IFA is the gold standard method for serological diagnosis of rickettsial infections ${ }^{16}$ but it presents some cross reactivity. Antibody titers against $R$. rickettsii are solely a proof of infection by a SFG rickettsia. Nevertheless, the high levels of antibody titers $(1,024$ to 4,096$)$ detected in seven horses and one donkey are a strong indicator of $R$. rickettsii being the cause of infection.

A high prevalence was also found among dogs, $81.3 \%$ of them had antibody titers of 64 and 128 . This prevalence value is higher than others previously reported for dogs from BSF-endemic areas in Minas Gerais $(13.68 \%)$ and São Paulo (25 to $66 \%)^{12,17,18}$. In spite of horses been a better sentinel animal for BSF (as they are primary hosts for A. cajennense ticks), dogs can be responsible for bringing infected ticks to the home environment and increasing the risk of human infection.

In the present study, four out of six humans with detectable antibodies against $R$. rickettsii had a history of BSF: three had been hospitalized and medicated, and one had been treated without any symptoms, because in a previous field research he presented detectable antibodies for $R$. rickettsii (data not shown). The remaining two were children (nine and 11 years old) that had never showed any symptoms. The mother of the youngest children had died five months earlier due to a confirmed case of BSF. The 11-year old child was the only female among the six persons with anti- $R$. rickettsii antibodies.
A number of host factors appear to affect the severity of human infection due to $R$. rickettsii. Increasing age is followed by a higher fatality $^{33}$, males have higher risk of dying than females despite the age group $^{10}$ and glucose 6-phosphate dehydrogenase (G6PD) deficiency, commonly identified in black individuals, seems related to severe and/or fatal disease. In the United States this deficiency affects approximately $12 \%$ of African-American males (CDC webpage). We do not have any data on the G6PD deficiency for the villagers but the fact they are all African descendents and several fatal cases have been reported for the area might be an indicator of such deficiency.

In our study we collected 356 A. cajennense adult ticks and none of them demonstrated to contain rikettsiae by the hemolymph test or by PCR. In a previous work, 810 adult $A$. cajennense ticks from three farms in a São Paulo BSF-endemic area were tested and none of them was infected by rickettsiae ${ }^{30}$. On the other hand, also in Brazil, GUEDES et. al. ${ }^{9}$ reported at least one $(1.28 \%) R$. rickettsii-infected $A$. cajennense tick out of 78 specimens collected from a BSF-endemic area at Coronel Pacheco, Minas Gerais, and PINTER \& LABRUNA ${ }^{26}$ reported six $(0.89 \%)$ out of 669 A. aureolatum ticks infected by $R$. rickettsii in a BSF-endemic area of the state of São Paulo. Earlier studies performed with Dermacentor variabilis ticks in endemic areas of the United States reported 0.05 to $1.3 \%$ of $R$. rickettsii-infected ticks. In one of these areas, only one out of 2,123 ticks was infected ${ }^{3}$ Even though the infection rates of $R$. rickettsii in its vector populations seems to be a dynamic process, the lethal effect of $R$. rickettsii for the ticks is a possible cause of low rates of infected adults, as it has been demonstrated in Dermacentor andersoni ticks ${ }^{22}$. Thus, as in the study performed by SANGIONI et. al. ${ }^{30}$, it is possible that we would have detected rickettsial DNA if we had examined a larger sample of ticks.

Low rates of infected adult ticks in endemic areas lead us to consider the importance of vertebrate hosts and their influence in the maintenance of rickettsiae in nature. It is known that some small animals are highly susceptible to rickettsial infections and could behave as amplifier hosts ${ }^{3}$. In Brazil, capybaras are believed to play an important role in the ecology of BSF ${ }^{15,24}$. Unlike others BSF-endemic areas ${ }^{12,18,30}$, capybaras seem to be absent in Capoeirão Village. Further studies are needed to identify the animal(s) involved in the ecology of BSF in the present area.

The Itabira Municipal Health Department had initiated a preventive program in Capoeirão Village in 1999. The program included visits to the village in order to perform tick control fumigation on animals, and guidance for the villagers about different ways of avoiding home infestation by ticks. Every villager would also have a special identity card, 
VIANNA, M.C.B.; HORTA, M.C.; SANGIONI, L.A.; CORTEZ, A.; SOARES, R.M.; MAFRA, C.L.; GALVÃO, M.A.M.; LABRUNA, M.B. \& GENNARI, S.M. - Rickettsial spotted fever in Capoeirão village, Itabira, Minas Gerais, Brazil. Rev. Inst. Med. trop. S. Paulo, 50(5): 297-301, 2008.

to be used at any health unit, with summarized instructions to doctors/ nurses related to BSF possible infection.

Cases of BSF had decreased in Itabira during the last years. One of the reasons for this marked decrease might be the smaller size of the $A$. cajennense population in the village, due to intensive acaricide usage promoted by the Municipality Health Department. However, unknown causes driving the dynamics of $R$. rickettsii within tick populations might also have played a role.

\section{RESUMO}

\section{Rickettsiose do grupo da febre maculosa na Vila de Capoeirão, Itabira, Minas Gerais, Brasil}

O presente estudo investigou a infecção por rickéttsias do grupo da febre maculosa (GFM) em área endêmica para febre maculosa brasileira (FMB; causada por Rickettsia rickettsii) no Estado de Minas Gerais, Brasil. Amostras de soros de humanos, cães e eqüídeos, e carrapatos Amblyomma cajennense adultos colhidos em um povoado rural em Itabira, Minas Gerais foram testados para infecção por Rickettsia. Pela Reação de Imunofluorescência Indireta (RIFI) foram detectados anticorpos anti- $R$. rickettsii em $8,2 \%$ dos soros humanos, $81,3 \%$ dos cães e em $100 \%$ dos eqüídeos. Nenhum dos 356 carrapatos se mostrou positivo para Rickettsia no teste de hemolinfa e na reação em cadeia pela polimerase (PCR) objetivando amplificar fragmentos de DNA dos genes $h t r A$ and the gltA. Os resultados sorológicos em eqüinos e cães (sentinelas para FMB) apontam para a circulação de uma rickéttsia do GFM na área do estudo, porém, numa freqüência de infecção muito baixa na população do carrapato $A$. cajennense.

\section{ACKNOWLEDGEMENTS}

This work was supported by "Fundação de Amparo à Pesquisa do Estado de São Paulo" (FAPESP) and the Municipal Health Service of Itabira.

\section{REFERENCES}

1. ARAGÃO, H. \& FONSECA, F. - Notas de ixodologia. V. A propósito da validade de algumas espécies do gênero Amblyomma do continente americano (Acari: Ixodidae). Mem. Inst. Oswaldo Cruz, 51: 485-492, 1953.

2. BURGDORFER, W. - The hemolymph test. A technique for detection of rickettsiae in ticks. Amer. J. trop. Med. Hyg., 19: 1010-1014, 1970.

3. BURGDORFER, W. - Ecological and epidemiological considerations of Rocky Mountain spotted fever and scrub typhus. In: WALKER, D.H. Biology of rickettsial diseases. Boca Raton, CRC, 1988. v. 1, p. 33-50.

4. CASTAGNOLLI, K.C.; FIGUEIREDO, L.B.; SANTANA, D.A. et. al. - Acquired resistance of horses to Amblyomma cajennense (Fabricius, 1787) ticks. Vet. Parasit., 117: 271-283, 2003.

5. CVE - Centro de Vigilância Epidemiológica, Governo do Estado de São Paulo. (http:// www.cve.saude.sp.gov.br/htm/cve fmb.html) accessed on 14 September 2007.

6. GALVÃO, M.A.M. - Febre maculosa em Minas Gerais: um estudo sobre a distribuição da doença no Estado e seu comportamento em área de foco periurbano. Belo Horizonte, 1996. (Tese de Doutorado - Faculdade de Medicina da Universidade Federal de Minas Gerais).
7. GALVÃO, M.A.M.; CALIC, S.B.; CHAMONE, C.B. et. al. - Spotted fever rickettsiosis in Coronel Fabriciano, Minas Gerais State. Rev. Soc. bras. Med. trop., 36: 479-481, 2003

8. GIMENEZ, D.F. - Staining Rickettsiae in yolk-sac cultures. Stain Technol., 39: $135-140,1964$

9. GUEDES, E.; LEITE, R.C.; PRATA, M.C.A. et. al. - Detection of Rickettsia rickettsi in the tick Amblyomma cajennense in a new Brazilian spotted fever-endemic area in the state of Minas Gerais. Mem. Inst. Oswaldo Cruz, 100: 841-845, 2005.

10. HATTWICK, M.A.W.; O'BRIEN, R.J. \& HANSON, B.F. - Rocky Mountain Spotted Fever: epidemiology of an increasing problem. Ann. intern. Med., 84: 732-739, 1976.

11. HIGUCHI, R. - PCR Technology - Principles and applications for DNA amplification. New York, Stockton, 1989. p. 31-38.

12. HORTA, M.C.; LABRUNA, M.B.; SANGIONI, L.A. et. al. - Prevalence of antibodies to spotted fever group rickettsiae in humans and domestic animals in a Brazilian spotted fever endemic area in the state of São Paulo, Brazil: serological evidence for infection by Rickettsia rickettsii and another spotted fever group rickettsia. Amer. J. trop. Med. Hyg., 71: 93-97, 2004.

13. LABRUNA, M.B.; KERBER, C.E.; FERREIRA, F. et. al. - Risk factors to tick infestations and their occurrence on horses in the state of São Paulo, Brazil. Vet. Parasit., 97: 1-14, 2001.

14. LABRUNA, M.B.; KASAI, N.; FERREIRA, F.; FACCINI, J.L. \& GENNARI, S.M - Seasonal dynamics of ticks (Acari: Ixodidae) on horses in the state of São Paulo, Brazil. Vet. Parasit., 105: 65-77, 2002.

15. LABRUNA, M.B.; WHITWORTH, T.; HORTA, M.C. et. al. - Rickettsia species infecting Amblyomma cooperi ticks from an area in the State of São Paulo, Brazil, where Brazilian spotted fever is endemic. J. clin. Microbiol., 42: 90-98, 2004.

16. LA-SCOLA, B. \& RAOULT, D. - Laboratory diagnosis of rickettsioses: current approaches to diagnosis of old and new rickettsial diseases. J. clin. Microbiol., 35: 2715-2727, 1997.

17. LEMOS, E.R.S.; MACHADO, R.D. \& COURA, J.R. - Rocky Mountain spotted fever in an endemic area in Minas Gerais, Brazil. Mem. Inst. Oswaldo Cruz, 89: 497-501, 1994

18. LEMOS, E.R.S.; MACHADO, R.D.; COURA, J.R.; GUIMARÃES, M.A. \& CHAGAS, N. - Epidemiological aspects of the Brazilian spotted fever: serological survey of dogs and horses in an endemic area in the state of São Paulo, Brazil. Rev. Inst. Med. trop. S. Paulo, 38: 427-430, 1996.

19. LEMOS, E.R.; ALVARENGA, F.B.; CINTRA, M.L. et. al. - Spotted fever in Brazil: a seroepidemiological study and description of clinical cases in an endemic area in the state of São Paulo. Amer. J. trop. Med. Hyg., 65: 329-334, 2001.

20. LEMOS, E.R.; ROZENTAL, T. \& VILLELA, C.L. - Brazilian spotted fever description of a fatal clinical case in the State of Rio de Janeiro. Rev. Soc. bras. Med. trop., 35: 523-525, 2002.

21. LIMA, V.L.; SOUZA, S.S.; SOUZA, C.E. et. al. - Spotted fever in Campinas region, State of São Paulo, Brazil. Cadern. Saúde públ. (Rio de J.), 19: 331-334, 2003.

22. NIEBYLSKI, M.L.; PEACOCK, M.G. \& SCHAN, T.G. - Lethal effect of Rickettsia rickettsii on its tick vector (Dermacentor andersoni). Appl. environ. Microbiol., 65: 773-778, 1999

23. OLIVEIRA, P.R. - Amblyomma cajennense (Fabricius, 1787) (Acari:Ixodixae). Avaliação de técnicas para o estudo de dinâmica populacional e biotecnologia. Belo Horizonte, 1998. (Tese de Doutorado - Curso de Pós-graduação em Medicina Veterinária, Escola de Veterinária, Universidade Federal de Minas Gerais). 

Capoeirão village, Itabira, Minas Gerais, Brazil. Rev. Inst. Med. trop. S. Paulo, 50(5): 297-301, 2008.

24. PACHECO, R.C.; HORTA, M.C.; MORAES-FILHO, J. et. al. - Rickettsial infection in capybaras (Hydrochaeris hydrochoerus) from São Paulo, Brazil: serological evidence for infection by Rickettsia bellii and Rickettsia parkeri. Biomedica, 27: 364-371, 2007.

25. PAROLA, P.; DAVOUST, B. \& RAOULT, D. - Tick - and flea-borne rickettsial emerging zoonoses. Vet. Res., 36: 469-492, 2005

26. PINTER, A. \& LABRUNA, M.B. - Isolation of Rickettsia rickettsii and Rickettsia bellii in cell culture from the tick Amblyomma aureolatum in Brazil. Ann. N.Y.Acad. Sci., 1078: 523-529, 2006.

27. PIZA, J.T.; MEYER, J.R. \& SALLES-GOMES, L. - Tifo exanthemático de São Paulo. São Paulo, Sociedade Impressora Paulista, 1932. p. 11-119.

28. REGNERY, R.L.; SPRUILL, C.L. \& PLIKAYTIS, B.D. - Genotypic identification of Rickettsiae and estimation of intraspecies sequence divergence for portions of two rickettsial genes. J. Bact., 173: 1576-1589, 1991.

29. ROZENTAL, T.; BUSTAMANTE, M.C.; AMORIM, M.; SERRA-FREIRE, N.M. \& LEMOS, E.R. - Evidence of spotted fever group rickettsiae in state of Rio de Janeiro, Brazil. Rev. Inst. Med. trop. S. Paulo, 44: 155-158, 2002.

30. SANGIONI, L.A.; HORTA, M.C.; VIANNA, M.C.B. et. al. - Rickettsial infection in animals and Brazilian spotted fever endemicity. Emerg. infect. Dis., 11: 265-269, 2005 .
31. SCHRIEFER, M.E.; SACCI Jr., J.B.; DUMLER, V.S.; BULLEN, M.G. \& AZAD, A.F. - Identification of a novel rickettsial infection in a patient diagnosed with murine typhus. J. clin. Microbiol., 34: 949-954, 1994

32. SEXTON, D.J.; MUNIZ, M.; COREY, G.R. et. al. - Brazilian spotted fever in Espírito Santo, Brazil: description of a focus of infection in a new endemic region. Amer. J. trop. Med. Hyg., 49: 222-226, 1993.

33. SEXTON, D.J. \& BREITSCHWERDT, E.B. - Rocky Mountain spotted fever. In PALMER, S.R.; SOULSBY, L. \& SIMPSON, D.I.H. Zoonoses: biology, clinical pratice, and public health control. Oxford, Oxford University Press, 1998. p. 207 215.

34. WEBB, L.; CARL, M.; MALLOY, D.C.; DASCH, G.A. \& AZAD, A.F. - Detection of murine typhus infection in fleas by using the polymerase chain reaction. J. clin. Microbiol., 28: 530-534, 1990 .

35. ZAVALA-VELAZQUEZ, J.E.; YU, X.J. \& WALKER, D.H. - Unrecognized spotted fever group rickettsiosis masquerading as dengue fever in Mexico. Amer. J. trop. Med. Hyg., 55: 157-159, 1996.

Received: 18 October 2007

Accepted: 16 July 2008 